\title{
Current scenario in the European edible-insect industry: a preliminary study
}

\author{
L. Pippinato, L. Gasco", G. Di Vita and T. Mancuso \\ Department of Agricultural, Forest and Food Science, University of Turin, Largo Paolo Braccini 2, 10095 Grugliasco, Italy; \\ laura.gasco@unito.it
}

Received: 27 January 2020 / Accepted: 12 March 2020

(c) 2020 Wageningen Academic Publishers

OPEN ACCESS C(1) (2) RESEARCH ARTICLE

\begin{abstract}
In recent years, there has been a growing interest in the novel food market due to the growing demand for proteinrich food and the diversification of the protein sources currently used. The edible insect and insect based-food sector has recently experienced an increase in the quantities produced and traded. This increase has occurred thanks to awareness-raising actions and the development of European regulations. The limited development of this sector does not permit in-depth market and business analyses, since it is still in formation, which means that it is still a relatively unexplored field of study, especially on the European scene. The objective of this study is to carry out a preliminary investigation of the consistency, typology and product assortment of the companies located in the European Union and which are focused on the production and marketing of insect-based products. The survey was performed through the investigation of the E-commerce catalogues and Internet websites of the companies. The study also focuses on the main insect species used, the origin of the raw material used and the prices of products currently available on the European market. The results show that companies are mainly located in the northern European countries and that the most used distribution channels are the E-commerce websites, compared to physical retail outlets. Most companies also buy their raw material from third party companies, even non-European ones, and then process or only resell the product. The products which sold the most were whole insects or insect meal, mainly based on Tenebrio molitor or Acheta domesticus. Prices showed a high variability, in particular related to the species used and how it is packaged.
\end{abstract}

Keywords: novel food, insect farming, channel distribution, insect price

\section{Introduction}

Owing to the global demand for protein-rich food, in recent years, we have witnessed the growth of novel environmentally-friendly and sustainable food products. The increasing world demand for meat and vegetable proteins (Di Vita et al., 2019; Kim et al., 2019) creates the need to look for novel protein sources (Henchion et al., 2017). With the aim of both satisfying the increasing food demand due to growing demographic trends worldwide and diversifying the emerging novel food trends in the most developed countries, non-traditional sources of protein have gained increasing importance. Many scientists identify insects as one of the more sustainable sources of nutrients able to satisfy global food needs (Henchion et al., 2017). The nutritional value of insects is species specific and the protein fraction is the most represented. On a dry matter basis, proteins in insects range from 12 to $69 \%$ (Bessa et al., in press; Rumpold and Schlüter, 2013). Being of animal origin, proteins from insects are of high biological value, containing valuable amounts of essential amino acids (EAA) able to contribute in a substantial way to the daily EAA requirements of adults and young people (Bessa et al., in press). Insects are also rich in energy: depending on the species, their lipid content can be up to 70\% (in dry matter) (Chen et al., 2010; Payne et al., 2016) with a fatty acid profile dramatically linked to the rearing substrate. Moreover, insects are also rich in minerals and elements such as phosphorus, potassium, iron, copper, zinc, manganese, sodium, and in vitamins (vitamin B1 and B2 and niacin) deemed to be important for human nutrition (Bukkens and Paoletti, 2005; Payne et al., 2016). For these reasons edible insect production has progressively gained importance and the global edible insects market is constantly increasing, 
both as food and as feed (Gasco et al., 2019; Kim et al., 2019; Lock et al., 2018; Mancuso et al., 2016, 2019; Sogari et al., 2019a; Van Huis, 2019).

According to both academics and business operators, entomophagy has received wide attention from industry and consumers (Van Huis and Tomberlin, 2017; Shelomi, 2015). Producers have put more effort into developing new products based on simple raw materials (e.g. whole freeze-dried insects) as well as more sophisticated insectbased processed food (e.g. protein bars, crackers and bread, alcohol), while consumers on the contrary, do not always appear to be prepared to accept such foods (Castro and Chambers, 2018; Cunha et al., 2015; Hartmann and Siegrist, 2017; Sogari et al., 2019a).

Furthermore, recent trends have shown a global increase in the number of producers as well as in the numbers of consumers, despite the aversion of many consumers to this specific novel food. A recent study forecasts that by 2030 the global edible-insects market will reach almost 8 bn USD, with a volume of 730,000 tons (Meticulous Research, 2019).

Despite the existence of many studies on the importance of edible insects as alternative protein sources, most of the empirical studies on the edible insect market are mainly focused on consumer behaviour and attitudes (House, 2016). These studies mainly addressed evaluating the acceptance and the willingness of the consumer to pay for them (Lombardi et al., 2019; Sogari et al., 2019b). Many studies highlight the Neophobia index and the aversion to insects by consumers (Melgar-Lalanne et al., 2019). On the contrary, a relatively limited strand of literature has been focused on investigating technical and management aspects of insect farming in order to assess production costs, profits, marketing and supply chain aspects (Hanboonsong et al., 2013).

Trading channels of edible insects vary by country. In Asian countries, such as Thailand, there exist different sales channels, but they are mainly based on short supply chains that generate small-scale channel distribution. Indeed, harvested or farmed insects can be sold by wholesale buyers or they can be traded in local markets directly by those who pick or breed them (Hanboonsong et al., 2013). At the same time, other authors reported the increasing importance of urban area markets, where insects are traded by street vendors and restaurants (Durst and Hanboonsong, 2015). Another recent trend consists of the development of supermarkets and convenience stores that offer ready-toeat processed insects (Durst and Hanboonsong, 2015). In Africa, trading channels have been divided into the direct channel (vendors directly selling insects to consumers), and the indirect short channels, consisting of retailers who buy insects from producers and sell them in local markets (Badanaro et al., 2014). Concerning the European Union, the trading channels are not so uniform, since regulation depends not only on the EU framework but also on a national basis in certain countries.

With regard to the complex legislative framework of novel foods, in which insects or their preparation are included, Lotta (2019) and IPIFF (2019a) argued the current legal context in the European Union highlighting the role of national and European bodies involved in authorisations release to trade the insects-based products. European Food Safety Authority (EFSA) is part of the governance on this matter, as well as other more recent EU regulations ${ }^{1}$.

In the panorama of the European agro-food system, Regulation (EU) 2015/2283 (EC, 2015), which allows the introduction of 'novel foods' became applicable on $1^{\text {st }}$ January 2018. The European Commission which regulates this matter, has the right to authorise or update the authorisation regarding the sales of a novel food (IPIFF, 2019a), but the legislative framework remains complex. Every company must be authorised to commercialise the novel food. Hence the new procedure has been described in Regulation (EU) 2015/2283 and other implementing regulations.

To date, there is a package of measures which, if respected, allows a company to sell insects as food. In the following, some references to the legislative framework in force to date is provided. 'Article 35(2) of Regulation (EU) 2015/22832 provides for transitional measures that aim to ensure that products lawfully commercialised in a Member State of the EU before Regulation (EU) 2015/2283 became applicable (i.e. before $1^{\text {st }}$ January 2018) may remain on the market of this particular Member State for a given period of time, subject to certain conditions' (IPIFF, 2019a: \$4.8). 'Only the EU countries applying the so-called novel food transitional measure (Finland, Denmark, the United Kingdom, the Netherlands, Czech Republic, Belgium, certain states in

\footnotetext{
${ }^{1}$ Reg. EU 2017/2468 (concerning traditional foods from third countries; EC, 2017a), Reg. EU 2017/2469 (administrative and scientific requirements for applications; EC, 2017b), Reg. EU 2017/2470 (the Union list of novel foods; EC, 2017c), Reg. EU 2017/625 (requirements for the entry into the Union; EC, 2017d).
}

\footnotetext{
${ }^{2}$ Reg. EU 2015/2283 (EC, 2015), art. 35 (2), Transitional measures: foods not falling within the scope of Regulation (EC) No 258/97, which are lawfully placed on the market by 1 January 2018 and which fall within the scope of this regulation may continue to be placed on the market until a decision is taken in accordance with Articles 10 to 12 or Articles 14 to 19 of this regulation following an application for authorisation of a novel food or a notification of a traditional food from a third country submitted by the date specified in the implementing rules adopted in accordance with Article 13 or 20 of this regulation respectively, but no later than 2 January 2020 .
} 
Germany) had allowed the commercialisation of insects as food, and Finland, Denmark and the United Kingdom had also allowed commercialisation when originating from EU third countries' (IPIFF, 2019c). Denmark, Finland, Austria, the Netherlands, the United Kingdom (IPIFF, 2019a), had applied national and European legislation to authorise companies to produce, hence in these countries the innovative food insect-based companies have been encouraged to scale up their expertise. In Belgium and Germany, it seems that tolerance would be applied to the producers, in France the situation is not so clear. Importation of whole insects or their parts from anywhere in the world was allowed in Denmark, Finland and the United Kingdom by authorisation or following specific procedures. In March, April and November 2019 the legislative framework were updated, by a 'package' of EU regulations: Reg. EU 2019/625 (update Regulation EU $625 / 2017$ requirements for entry into the Union) (EC, 2019), Regulation EU 2019/626 regarding a list of countries authorised to export insects in the EU, and Regulation EU 2019/1981 where some countries - Canada, South Korea and Switzerland - have been authorised to export insects into the EU; Regulation EU 2019/628 which establishes a model official certificate for insects as food imported into the EU. In this way, EU Member States benefiting from the so-called 'novel food transitional measure' have to cease imports of insect food products if not originating from the three EU third countries Canada, South Korea and Switzerland (IPIFF, 2019c). Nevertheless, the European Commission services hope to be able to expand and update the list.

Manufacturers must also pay close attention to the labelling of the product on the basis of Regulation EU 2011/1169 (EC, 2011). Regarding insect-based products, Food Regulation CE 2002/178 (EC, 2002) is fully implemented. Lotta (2019) underlines that some European regulations have to be updated about the insect market, such as regulations about the risks (the regulations are dated 2005, 2006 and 2010) and the hygiene rules (the regulation is dated 2004).

Considering that scenario analysis is crucial for the future development of the innovative agricultural and food sector (Di Vita et al., 2015) and given a certain paucity of studies and statistical data on the modern supply side, this research investigates these latter relationships in a novel and emerging food sector such as the edible insect industry. As a consequence, for the first time, a description of the current state of the edible insect industry throughout the European Union is provided. The main objective of the present study is to define the current scenario of the supply of insects for human use (food and cosmetics), providing a framework that allows to identify the main aspects and characteristics of the EU edible insect supply in order to identify challenges and opportunities for insect-food producers in the EU.

\section{Method}

Data were collected through an online survey of the current universe of EU producers by analysing their websites, by means of the main search engines and specialised forums. According to the insights of several studies (Anesbury et al., 2016; Cristobal-Fransi et al., 2020; Kasemsap, 2018), analysis using a systematic approach of the website of food companies allows to collect a large amount of data on structural features, production and prices of the EU edible-insect industry.

The analysis of the content of websites can be focused on specific goals, and various methods are applied, as shown in Henry and Story (2009) and Weber et al. (2006), where a content analysis methodology of the websites of food manufacturers was set up.

In the present study, care was taken to analyse content using specific keywords only. The keywords employed were the following: 'insect food,' 'novel food,' 'insect farm' and 'insect products.' Furthermore, the survey excluded all the activities of firms focused on the production of insects for feed use and all those not located within the territory of the EU.

In order to create the dataset, information on the type of activity, the marketing approach, the types of products, their sales formats and related nutritional information, in particular taking into account the protein and fat content, the types of insects used and their origin was collected. Special attention was paid to the prices of the different types of products.

Prices were collected for all products in their original sales format and in their original currency, because not all the surveyed countries use the Euro as their currency. In order to compare the observations, data have been converted into Euros and all have been referred to a format of $100 \mathrm{~g}$ of entire insect-based product ready to eat.

Concerning the typology of sales channels, the activities were classified as 'e-commerce sales' and 'physical sales. The former was divided into: (1) e-commerce and processing, whereby the company transforms the raw material itself and sells the finished product; (2) e-commerce and production, when the supply chain is complete and the company also produces the raw material itself; and (3) e-commerce retailer, if the activity is only involved in the resale of thirdparty products.

On the other hand, companies with physical sales, have been divided into: (1) farm and processing, if they produce and process the raw material directly; (2) catering and restaurants, where the activities are only concerned with the final transformation for the customer; and (3) shops, where activities are dedicated only to sales. 
A classification of the product typology presently available at markets was carried out, by classifying them in the four following categories: (1) entire insect, where the product consists of the whole insect, still recognisable in its parts and cooked, dehydrated or freeze-dried; (2) meal, in the case of protein flour or powders obtained by grinding the insects themselves; (3) protein bars, in the case of products mainly oriented to sports nutrition, consisting of variable percentages of insect flour, in order to increase the protein content; and (4) other, a category that includes all the different formats of snacks, protein pasta, meats or alcohol not classifiable in the other categories.

\section{Results}

\section{Features of the European edible insect industry}

This section reports the main results on localisation amount, distribution channels, productive process and business activities, grown and traded insect species, typology of products by species and insect content and average price by product of surveyed companies. As shown in Table 1 , our outcomes revealed the presence of 59 companies involved in the production, processing or sale of insectbased food products, which are highlighted. The business core is concentrated in northern European countries, with the United Kingdom, Germany and Belgium showing the highest number of activities (Figure 1), followed by the Netherlands, France, Finland and Denmark.

This phenomenon may also be partly due to the positive attitude that northern consumers have towards these products, which seems to be higher than the rest of European consumers (Piha et al., 2018). But it is also certainly attributable to different legislation in different EU countries, due to the fact that the safety controls and trade norms of edible insects have been subject to different

Table 1. Number of companies by country.

\begin{tabular}{lcccr} 
Country & E-commerce & Physical sale & Total & \multicolumn{1}{c}{$\%$} \\
Austria & 2 & - & 2 & 3.4 \\
Belgium & 3 & 4 & 7 & 11.8 \\
Denmark & 4 & 1 & 5 & 8.5 \\
Finland & 4 & 1 & 5 & 8.5 \\
France & 5 & 1 & 6 & 10.2 \\
Germany & 6 & 1 & 7 & 11.8 \\
Italy & 1 & - & 1 & 1.7 \\
The Netherlands & 4 & 2 & 6 & 10.2 \\
Norway & 1 & - & 1 & 1.7 \\
Spain & 4 & - & 4 & 6.8 \\
Sweden & 1 & - & 1 & 1.7 \\
United Kingdom & 13 & 1 & 14 & 23.7 \\
Total & 48 & 11 & 59 &
\end{tabular}

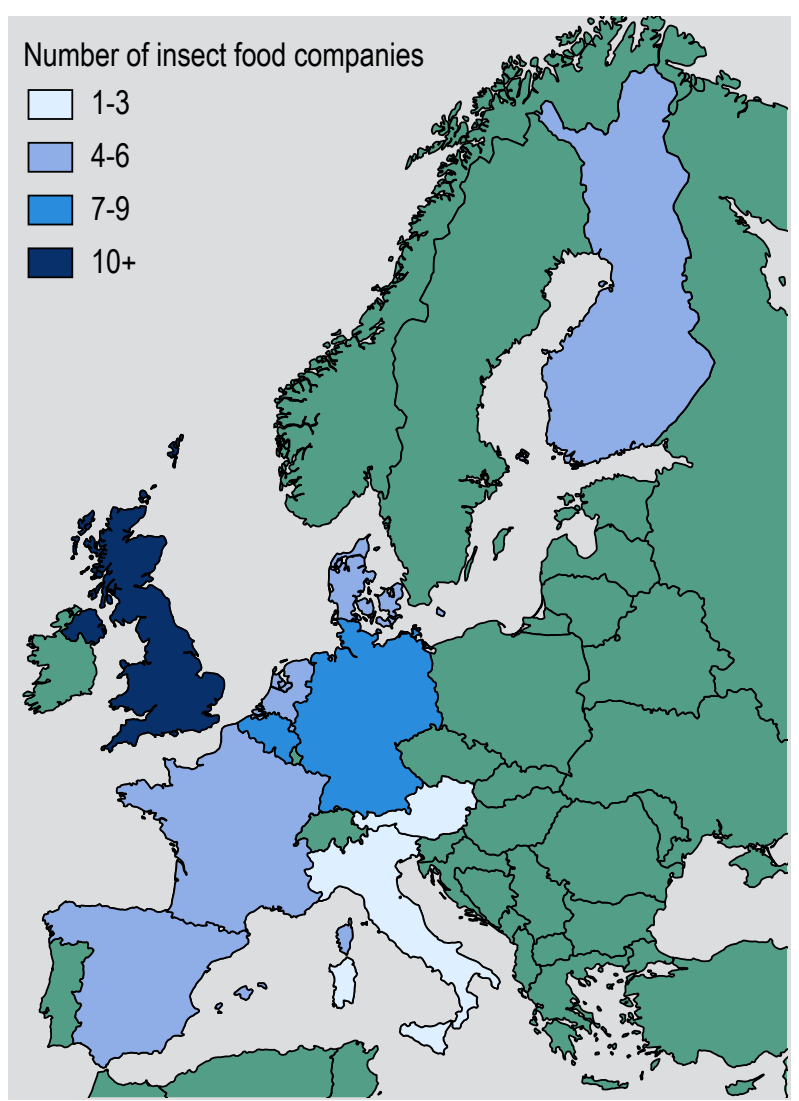

Figure 1. Spatial distribution of insect food companies in the EU.

national regulations and thanks to the favourable 'novel food transitional measures' ${ }^{3}$ and the previous ones (IPIFF, 2019a).

The relevance of the main distribution channels was also explored. In this regard, the predominance of e-commerce was observed. It has progressively gained importance in the food sector as well and many authors have analysed in depth the impact of e-commerce on several sectors such as the agro-food industry (Baourakis et al., 2002; Canavari et al., 2010). E-commerce is now a well-established form of trade all over Europe (Carpio and Lange, 2015).

The adoption of e-commerce is not only crucial for traditional or conventional food, but it also becomes strategic for the enterprises involved in more innovative production such as edible insects. Indeed, $82 \%$ of the companies examined only use e-commerce for the sale of their products (Table 2). The choice of this type of marketing is probably due to the possibilities of reducing storage and maintenance costs (Bodini and Zanoli, 2011) and to the possibility of reaching a much greater, more widespread and more distant group of customers interested in this kind of product. In addition, earlier studies highlighted many factors and elements linked to trust that allowed the uptake

\footnotetext{
${ }^{3}$ Reg. EU 2015/2283, art. 35 (2), Transitional measures (EC, 2015).
} 
Table 2. Main distribution channels.

$\begin{array}{lcc}\text { Type } & \begin{array}{l}\text { Companies } \\ \text { (n) }\end{array} & \begin{array}{l}\text { Of total } \\ (\%)\end{array} \\ \begin{array}{l}\text { Physical sale } \\ \quad \text { Farm and processing }\end{array} & 5 & \\ \quad \text { Catering and restaurant } & 4 & 45.4 \\ \text { Shop } & 2 & 36.4 \\ \quad \text { Total } & 11 & 18.2 \\ \text { E-commerce } & & 100 \\ \quad \text { E-commerce and processing } & 34 & \\ \text { E-commerce and production } & 7 & 70.8 \\ \text { E-commerce retailer } & 7 & 14.6 \\ \text { Total } & 48 & 14.6 \\ \end{array}$

of modern forms of commerce, such as e-commerce, even in the agro-food sector (Canavari et al., 2010).

Regarding physical sales, direct distribution by farms is the dominant retail format, followed by restaurants and specialised stores. The farm and processing category includes both medium and large-scale sized enterprises, focused mainly on the production process, and the smallscale activities built in an urban context.

From a legal point of view, in most cases it was not possible to identify the nature of the companies examined; however, it became clear that, especially in the category of retailing only, there are franchised outlets, while for companies dedicated to production and processing, there is a significant presence of start-ups or small independent companies.

Available data do not allow for information to be gathered about the production of raw materials or even about the supply for many of the companies examined. In fact, for the production process, many of them rely on the production of external firms which often operate in Belgium, the Netherlands, Denmark or France. Despite the lack of information about the raw material source, in the survey of companies it has been observed that, in particular for some exotic products, the country of origin indicated refers to extra-European areas, like Asia or South America, where these insects are considered traditional food. Nevertheless, the origin of insects, when imported, may change according to the new legislative framework referred to above.

The companies that process the raw material and then sell it (Table 3) are the majority of the sample detected (65.0\%), while only 12 companies out of 59 declare on their website that they are producing their own raw material.
Table 3. Type of companies by business activity.

$\begin{array}{lrc}\text { Type } & \mathbf{n} & \% \\ & & \\ \text { Production, processing and retailing } & 12 & 20.3 \\ \text { Processing and retailing } & 38 & 64.4 \\ \text { Only retailing } & 9 & 15.3 \\ \text { Total } & 59 & 100\end{array}$

The production process and breeding protocols of the insect species are generally not specified. In spite of this, there are some small activities, especially in northern countries, whose main objective is to raise consumer awareness of novel food issues and to spread the development of the so-called urban plants, i.e. small farms that can be easily implemented even in areas with limited available space.

In the case of those firms that are mainly focused on the production of insect raw material, information on prices and quantity traded is often not provided directly.

Moreover, the companies examined can be categorised into two classes. The first specialises in sports nutrition/healthy nutrition, thus producing insect protein meal, energy bars or protein bars with varying percentages of insect meal, insect meal tout court and protein pasta with insect meal. The second class includes those companies more oriented toward the sale of snacks based on insects and the whole insect itself, with different sales formats available. In the case of whole insects, the types of preparation consist of the following main types: roasted, dried or freeze-dried.

With regard to the insect species which are grown and sold, the following four main species were identified: Acheta domesticus, Tenebrio molitor, Alphitobius diaperinus and Locusta migratoria. Table 4 reports the number of companies that present products with a distinct insect species in their catalogues. Included in the 'others' category are all minor or exotic species, which are generally imported from different areas of origin, typically from Asia or South America, where they are already widely and traditionally used as a food source.

Table 4. Number of companies that sell a specific insect species.

\begin{tabular}{|c|c|c|}
\hline Insect species & Companies (n) & $\begin{array}{l}\text { Of the total } \\
\text { companies (\%) }\end{array}$ \\
\hline Acheta domesticus & 35 & 58.3 \\
\hline Tenebrio molitor & 20 & 33.3 \\
\hline Alphitobius diaperinus & 16 & 26.7 \\
\hline Locusta migratoria & 10 & 16.7 \\
\hline Others & 25 & 43.4 \\
\hline
\end{tabular}


The survey showed use of the common cricket, followed by the mealworm. This trend is probably due to the greater availability of these species and to the management ability acquired by firms, which also employ these species as a feed source. Other reasons for their popularity can be ascribed to their high protein and fat content (Rumpold and Schlüter, 2013) as well as to the fact that some of them are quite easy to rear (Macombe et al., 2019).

Focusing on the typology of products traded, as reported in Table 5, it should be noted that the main type of product in the sector is the whole insect, with almost $50 \%$ of the entire market scene, followed by insect meal with about $20 \%$, according to the classification made for the Global Forecast 2030 (Meticulous Research, 2019). These are the two types of products that require a smaller number of processes and this is probably the reason why they are the most popular product in the stores' catalogues. On the other hand, considering the type of products related to the insect species used, it becomes evident that $A$. domesticus and T. molitor in the forms of whole insects and meal are the most readily available on the market. A. diaperinus is also frequently used, but to a lesser degree than the common cricket. Finally, L. migratoria plays the most marginal role among the four main species considered.

In addition to the main mandatory label information (proteins, fats and carbohydrates), many companies report other data about micronutrients and vitamins contained in their products, providing a better overview of the nutritional properties and advantages of a diet that also includes insects.
However, the percentage content of insects in food is highly variable and closely related to the type of product sold (Table 6). By considering the total of 190 different products surveyed, these can be broken down into three main categories on the basis of insect content percentage: $>90 \%$, between 90 and $10 \%$ and less than $10 \%$. While there is an obvious relationship between whole insect format and insect content $>90 \%$, which refers to the majority of products traded, insect meal has a more variable insect content percentage, but it is almost entirely in the range above $90 \%$. The reason for the prevalence of products with a high insect content is probably due to the easier handling and preparation process of the product consisting only of insects and due to the lower processing requirements compared to a product with a more complex production process and more ingredients.

In the case of protein bars, in fact, the content is most frequently below $10 \%$. On the other hand, the visibility of the insects is a strong driver of neophobia among insect-based products (Orsi et al., 2019), so other types of preparations, such as protein bars, pasta or snacks, could attract a larger number of consumers. Lastly, there are greater difficulties in finding such information for exotic insects or more generally for extra-European imported products.

Finally, Figure 2 displays a categorisation of products by insect species and type. The market of insect-based products shows a prevalence of whole insect-based formats, in different sizes and forms of preparation, followed by the meals. The protein bars format plays a more marginal role, perhaps due to the fact that these products are aimed at

Table 5. Number of products traded by insect species used.

$\begin{array}{llrrrrrr}\text { Product } & \text { Acheta domesticus } & \text { Tenebrio molitor } & \text { Alphitobius diaperinus } & \text { Locusta migratoria } & \text { Other } & \text { Total } & \% \\ \text { Entire insect } & 22 & 21 & 11 & 12 & 27 & 93 & 48.9 \\ \text { Meal } & 20 & 5 & 7 & 3 & 5 & 40 & 21.1 \\ \text { Protein bars } & 12 & 1 & 2 & - & 4 & 19 & 10.0 \\ \text { Other } & 15 & 7 & 5 & - & 11 & 38 & 20.0 \\ \text { Total } & 69 & 34 & 25 & 15 & 47 & 190 & \end{array}$

Table 6. Typology of products by insect percentage content.

\begin{tabular}{|c|c|c|c|c|c|c|}
\hline Insect \% & Entire insect & Meal & Protein bars & Other & Total & $\%$ \\
\hline$>90$ & 93 & 33 & - & 4 & 130 & 68.4 \\
\hline $90>x>10$ & - & 2 & 2 & 4 & 8 & 4.2 \\
\hline$<10$ & - & 1 & 9 & 9 & 19 & 10.0 \\
\hline n.a. & - & 4 & 8 & 21 & 33 & 17.4 \\
\hline Total & 93 & 40 & 19 & 38 & 190 & 100 \\
\hline
\end{tabular}




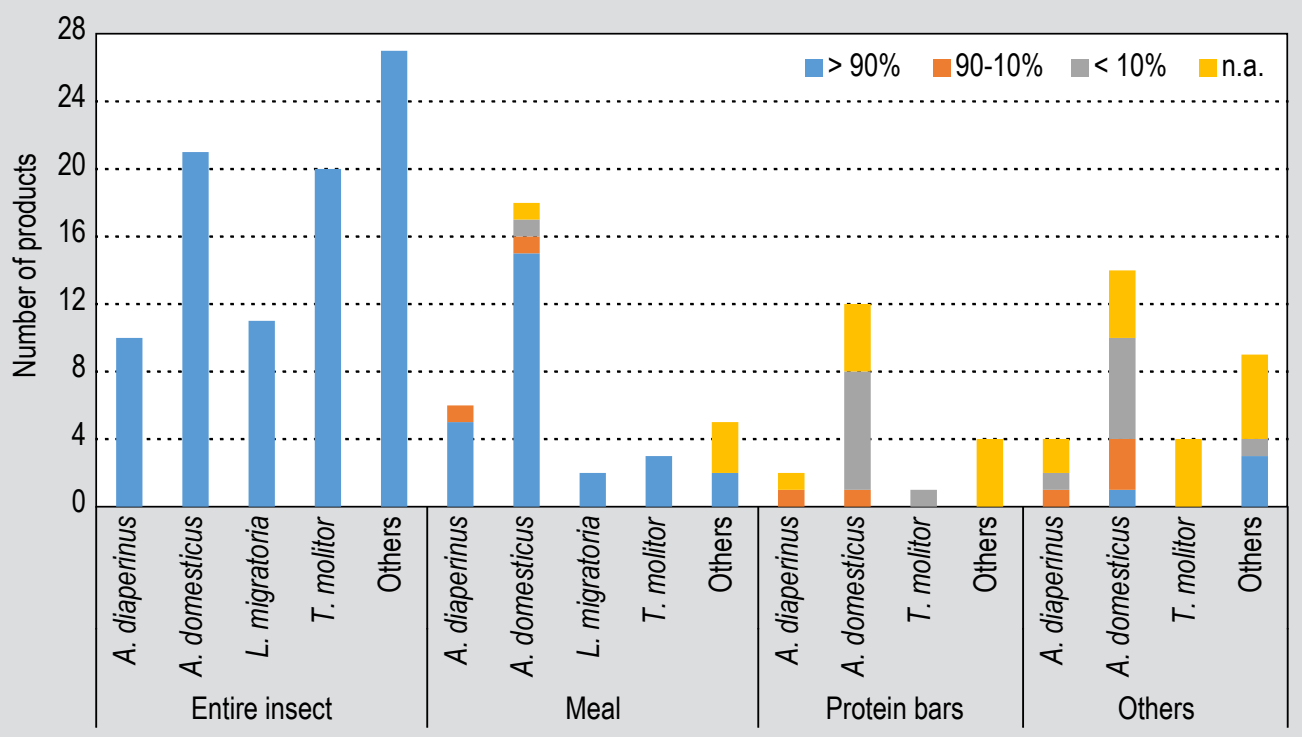

Figure 2. Number of products by insect species and typology of product.

a very specific consumer group, particularly athletes and people who adopt a protein-rich diet.

However, a substantial part of the market is made up of all those products, such as beers, protein pasta, meat or sauces, which must be considered as separate from the main categories of interest because of their specificity. The high percentage of such products can probably be ascribed to the producers' purpose of raising consumer interest, avoiding the negative effect on the consumers' perception caused by the visibility of the whole insect (Orsi et al., 2019). Moreover, among all the species found, the one that can be considered as the main reference in the panorama of novel insect food is A. domesticus, followed by T. molitor.

\section{Average prices of insect-based food products in the European market}

The different product prices in the catalogues were all referred to the standard format of $100 \mathrm{~g}$ of entire insectbased product, to be comparable to each other. However, the absence of such information for many of the products on sale, particularly in the case of sales of large quantities, did not allow us to obtain the data for all the products surveyed.

Table 7 shows the average prices for the product types investigated and related to the different insect species used. The highest prices are found in the case of whole insect products $(55.4 € / 100 \mathrm{~g}$ for whole $L$. migratoria), followed by insect meal $(49.5 € / 100 \mathrm{~g}$ again for L. migratoria). It is important to remember, however, that for some categories few products have been identified, as is the case of $L$. migratoria: this may lead to less reliable average price values, due to the low presence of these types of product on the market. For this reason, the values obtained for more widespread products such as those based on A. domesticus (37€/100 g for whole insects) and T. molitor $(17.1 € / 100 \mathrm{~g}$ for insect meal) appear more reliable.

Therefore, it is clear that the price is linked to the insect quantity in the product, with a trend that shows the highest prices for whole insects and the lowest prices for protein bars.

Table 7. Average prices (in $€ / 100 \mathrm{~g}$ ) for the different type of products related to the insect species used.

$\begin{array}{llccc} & \text { Entire insect } & \text { Meal } & \text { Protein bars } & \text { Other } \\ \text { Acheta domesticus } & & & & 4.5 \\ \text { Tenebrio molitor } & 37.0 & 12.8 & 4.3 & 9.9 \\ \text { Alphitobius diaperinus } & 22.1 & 17.1 & 2.0 & 4.8 \\ \text { Locusta migratoria } & 18.4 & 10.7 & 6.6 & - \\ \text { Other } & 55.4 & 49.5 & 4.8 & 16.5\end{array}$


What significantly influences the price of the products, however, is the sales format. The survey carried out shows that the smallest product formats have the highest average price per $100 \mathrm{~g}$. Table 8 shows the average prices for the product types according to the sales format.

Again, the whole insect has the highest average values ( $41.0 € / 100 \mathrm{~g}$ for sizes under $50 \mathrm{~g}$ ), followed by meal, with $27.1 € / 100 \mathrm{~g}$ (for the same size format). The sales format trend is clear for all the product categories concerned. The compact format, which is more attractive to the consumer attracted by the novelty of the product, combined with the cost of the packaging, therefore contribute to the significant price difference between size categories $(€ 19.2$ difference between the average prices of $>50 \mathrm{~g}$ and $50<\mathrm{x}<100 \mathrm{~g}$, in the case of whole insects).

\section{Discussion and conclusions}

Literature on insect consumption as food has been analysed in depth despite the fact that the studies regarding the dynamics and the strategies of companies involved in the production and trade of edible insects are scarce. That is why this paper has explored the main features of the edible insect industry supply in the European Union and presented a framework of main product typologies, the main insect species used, the spatial distribution of the enterprises detected as well as structural and distribution channels of the European insect sector.

This paper describes the current scenario of the insectbased European food industry for the first time. The market supply is currently managed by a small group of companies and demand is still extremely low. However, there is growing interest from potential consumers, while highly innovative companies are empowering and attracting investment from abroad.

The results highlight the fact that the majority of the enterprises are mainly located in northern European countries, focusing their activity on the processing and trade of the product. The survey also shows that whole insects and insect meal are the main typologies of insect- based food on the market, probably due to the facility of the production process. In addition, this research observed that the main distribution channel is e-commerce across all of Europe while A. domesticus and T. molitor are the most widespread insect species in the EU. The survey shows that the majority of the companies analysed does not breed their own raw insect material, but they acquire it from extra-European firms, mainly from Asia.

In conclusion, the prices in $€ / 100 \mathrm{~g}$ found by the market survey are high, especially for the product categories with the highest insect content (entire insect and meal); however, in addition to the insect content, the main driver of prices seems to be the sales format. In fact, smaller sales formats, as in the case of packaging below 50-100 g, have the highest prices.

In addition, the lower prices (more attractive to the consumer) for products such as protein bars or snacks, with a lower content of insect meal, also suggest that these types of product, where the insect component is not visible, are currently more acceptable to the consumer.

The data provided in this research allow to identify some possible scenarios, suggesting future trends. In this regard, it seems plausible to predict an increase in European rearing activities, thanks to the increasing potential of consumption, especially with regard to products containing insects that cannot be identified (protein bars and protein meal).

At the same time, this growth will have to be encouraged by a process of progressive liberalisation of the sales of these products, which can be further enhanced through a regulatory harmonisation of legislation among the European countries. In this direction, a survey of insect manufacturers showed that $64 \%$ of firm respondents stated that the EU and national regulatory context is one of the main factors affecting the growth of the European insect sector (IPIFF, 2019b). In fact, a proper collective legal framework regarding edible insect production in the EU such as Regulation (EU) $2015 / 2283$ (EC, 2015) and the even more recent EU Regulation 2019 'package' that has been added, orienting companies to build the most appropriate strategies.

Table 8. Average prices $(€ / 100 \mathrm{~g})$ by type of product and their sales format.

$\begin{array}{lcccc} & \text { Entire insect } & \text { Meal } & \text { Protein bars } & \text { Other } \\ & & & & 12.9 \\ 50 \mathrm{~g} & 41.0 & 27.1 & 8.4 & 10.8 \\ 50<\mathrm{x}<100 \mathrm{~g} & 21.8 & 16.4 & 4.4 & 4.9 \\ 100<\mathrm{x}<200 \mathrm{~g} & 27.9 & 7.6 & 2.4 & 3.5 \\ 200<\mathrm{x}<500 \mathrm{~g} & 3.0 & 7.5 & 3.6 & - \\ 500<\mathrm{x}<1000 \mathrm{~g} & 6.8 & 6.3 & 3.5 & - \\ >1000 \mathrm{~g} & - & - & 4.5 & 8.5 \\ \text { Total average prices } & 34.4 & 14.1 & & \end{array}$


The implementation of policies aimed at promoting the establishment of new insect-food enterprises and enhancing the existing ones, should be adequately supported by marketing strategies in order to spread a wider knowledge of these products to the consumer, and therefore reduce the neophobic component intrinsic in this type of food.

Unfortunately, the European insect-based novel foods market is still at an early stage, combined with a complex regulatory framework and a not always positive consumers' attitude towards insect-based food, and thus in the future will require a joint effort by the companies to offer more attractive products for the European consumer.

The progressive liberalisation of the edible-insect market in all EU countries makes it possible to consider this plausible and therefore expect to see sustained production growth in the main EU countries, where this has not yet taken place. At the same time, a consolidation of supply (production and expertise of enterprises) in northern Europe is likely.

It is also assumed that a gradual increase in the number of companies present on the market will lead to a moderate downward levelling of prices for all examined products (levelling down of average prices).

Finally, it is plausible to stick to an increase in demand due to the pull effect of meal and protein bars. Whole insects and meal could satisfy the demands of the food processing industry, while protein bars would increase the demand of those consumers who engage in sports regularly or follow balanced diets, ensuring a diversification of available proteins at markets due to their origin and to their environmental impact. In fact, despite recent studies highlighting that the environmental impact of insects bred for feed use is not low (Bosh et al., 2019; Smetana et al., 2019), the use of different rearing substrates, from a circular economy point of view (Le Féon et al., 2019), could make this production environmentally sustainable.

However, the lack of more specific data on companies, production methods and supply chain relations, as well as the current small number of companies in Europe, do not permit more detailed analyses on this market. This is compounded by the limited availability of pricing information, especially in the case of very large production that is sold wholesale.

Further analysis could be developed in the near future in order to evaluate the organisation of firms and their strategic approach to the sales market; in this direction many aspects linked to industry management deserve to be investigated more in depth, first of all in terms of the relationship between buyers and sellers all along the edible insect supply chain.

\section{Funding statement}

The publication derives from the research Project BIOSin (GASL_RIC_N_COMP_18_02) on 'Circular economybiomasses-new products: the sustainable bionconvertion of insects (BioSIn), which was funded by the CRT Foundation (Fondazione CRT), Torino, Italy.

\section{Conflict of interest}

The authors declare no conflict of interest.

\section{References}

Anesbury, Z., Nenycz-Thiel, M., Dawes, J. and Kennedy, R., 2016. How do shoppers behave online? An observational study of online grocery shopping. Journal of Consumer Behaviour 15: 261-270. https://doi.org/10.1002/cb.1566

Badanaro, F., Amevoin, K., Lamboni, C. and Amouzou, K., 2014. Edible Cirina forda (Westwood, 1849) (Lepidoptera: Saturniidae) caterpillar among Moba people of the Savannah Region in North Togo: from collector to consumer. Asian Journal of Applied Science and Engineering 3: 13-24. https://doi.org/10.15590/ajase/2014

Baourakis, G., Kourgiantakis, M. and Migdalas, A., 2002. The impact of e-commerce on agro-food marketing: the case of agricultural cooperatives, firms and consumers in Crete. British Food Journal 104: 580-590. https://doi.org/10.1108/00070700210425976

Bessa, L.W., Pieterse, E., Sigge, G. and Hoffman, L.C., in press. Insects as human food; from farm to fork. Journal of the Science of Food and Agriculture, https://doi.org/10.1002/jsfa.8860

Bodini, A. and Zanoli, R., 2011. Competitive factors of the agro-food e-commerce. Journal of Food Products Marketing 17: 241-260. https://doi.org/10.1080/10454446.2011.548696

Bosch, G., Van Zanten, H.H.E., Zamprogna, A., Veenenbos, M., Meijer, N.P., Van der Fels-Klerx, H.J. and Van Loon, J.J.A., 2019. Conversion of organic resources by black soldier fly larvae: legislation, efficiency and environmental impact. Journal of Cleaner Production 222: 355-363. https://doi.org/10.1016/j.jclepro.2019.02.270

Bukkens, S.G.F. and Paoletti, M.G., 2005. Insects in the human diet: nutritional aspects. In: Paoletti, M.G. (eds.) Ecological implications of minilivestock: potential of insects, rodents, frogs and snails. Science Publishers, Enfield, NH, USA, 608 pp. https://doi. org/10.1201/9781482294439

Canavari, M., Fritz, M., Hofstede, G.J., Matopoulos, A. and Vlachopoulou, M., 2010. The role of trust in the transition from traditional to electronic B2B relationships in agri-food chains. Computers and Electronics in Agriculture 70: 321-327. https:// doi.org/10.1016/j.compag.2009.08.014

Carpio, C.E. and Lange, K.Y., 2015. Trends in e-commerce for the food marketing system. CAB Reviews: Perspectives in Agriculture, Veterinary Science, Nutrition \& Natural Resources 10: 1-8. https:// doi.org/10.1079/PAVSNNR201510023

Castro, M. and Chambers, E., 2018. Willingness to eat an insect based product and impact on brand equity: a global perspective. Journal of Sensory Studies 34: e12486. https://doi.org/10.1111/joss.12486 
Chen, X., Feng, Y. and Zhang, H., 2010. Review of the nutritive value of edible insects. In: Durst, P.B., Johnson, D.V., Leslie, R.N. and Shono, K. (eds.) Forest insects as food: humans bite back. Proceedings of a workshop on Asia-Pacific resources and their potential for development. February 19-21, 2008. Food and Agriculture Organisation, Chang Mai, Thailand. Available at: http://www.fao. org/docrep/012/i1380e00.pdf

Cristobal-Fransi, E., Montegut-Salla, Y., Ferrer-Rosell, B. and Daries, N., 2020. Rural cooperatives in the digital age: an analysis of the Internet presence and degree of maturity of agri-food cooperatives' e-commerce. Journal of Rural Studies 74: 55-66. https://doi. org/10.1016/j.jrurstud.2019.11.011

Cunha, L.M., Gonçalves, A.T.S., Varela, P., Hersleth, M., Costa Neto, E.M., Grabowski, N.T., House, J., Santos, P. and De Moura, A.P., 2015. Adoption of insects as a source for food and feed production: a cross-cultural study on determinants of acceptance. In: Book of abstracts of the $11^{\text {th }}$ Pangborn Sensory Science Symposium, August 23-27, 2015, Gothenburg, Sweden.

Di Vita, G., Allegra, V. and Zarbà, A.S., 2015. Building scenarios: a qualitative approach to forecasting market developments for ornamental plants. International Journal of Business and Globalisation 15: 130-151. https://doi.org/10.1504/IJBG.2015.071152

Di Vita, G., Blanc, S., Brun, F., Bracco, S. and D’Amico, M., 2019. Quality attributes and harmful components of cured meats: exploring the attitudes of Italian consumers towards healthier cooked ham. Meat Science 155: 8-15. https://doi.org/10.1016/j.meatsci.2019.04.013

Durst, P.B. and Hanboonsong, Y., 2015. Small-scale production of edible insects for enhanced food security and rural livelihoods: experience from Thailand and Lao People's Democratic Republic. Journal of Insects as Food and Feed 1: 25-31. https://doi.org/10.3920/ JIFF2014.0019

European Commission (EC), 2002. Regulation (CE) 2002/178 laying down the general principles and requirements of food law, establishing the European Food Safety Authority and laying down procedures in matters of food safety. Official Journal of the European Communities 31: 1-24.

European Commission (EC), 2011. Regulation (EU) No 2011/1169 of $25^{\text {th }}$ October 2011 on the provision of food information to consumers. Official Journal of the European Union 304: 18-61.

European Commission (EC), 2015. Regulation (EU) 2015/2283 on novel foods, amending Regulation (EU) No 2011/1169 of the European Parliament and of the Council and repealing Regulation (EC) No 258/97 of the European Parliament and of the Council and Commission Regulation (EC) No 2001/1852. Official Journal of the European Union 327: 1-22.

European Commission (EC), 2017a. Commission Implementing Regulation (EU) 2017/2468 of $20^{\text {th }}$ December 2017 laying down administrative and scientific requirements concerning traditional foods from third countries in accordance with Regulation (EU) 2015/2283 of the European Parliament and of the Council on novel foods. Official Journal of the European Union 351: 55-60.

European Commission (EC), 2017b. Commission Implementing Regulation (EU) 2017/2469 of $20^{\text {th }}$ December 2017 laying down administrative and scientific requirements for applications referred to in Article 10 of Regulation (EU) 2015/2283 of the European Parliament and of the Council on novel foods. Official Journal of the European Union 351: 64-71.

European Commission (EC), 2017c. Commission Implementing Regulation (EU) 2017/2470 of $20^{\text {th }}$ December 2017 establishing the Union list of novel foods in accordance with Regulation (EU) 2015/2283 of the European Parliament and of the Council on novel foods. Official Journal of the European Union 351: 72-201.

European Commission (EC), 2017d. Regulation (EU) 2017/625 of the European Parliament and of the Council of 15 March 2017 on official controls and other official activities performed to ensure the application of food and feed law, rules on animal health and welfare, plant health and plant protection products, amending Regulations (EC) No 999/2001, (EC) No 396/2005, (EC) No 1069/2009, (EC) No 1107/2009, (EU) No 1151/2012, (EU) No 652/2014, (EU) 2016/429 and (EU) 2016/2031 of the European Parliament and of the Council, Council Regulations (EC) No 1/2005 and (EC) No 1099/2009 and Council Directives 98/58/EC, 1999/74/EC, 2007/43/EC, 2008/119/ EC and 2008/120/EC, and repealing Regulations (EC) No 854/2004 and (EC) No 882/2004 of the European Parliament and of the Council, Council Directives 89/608/EEC, 89/662/EEC, 90/425/ EEC, 91/496/EEC, 96/23/EC, 96/93/EC and 97/78/EC and Council Decision 92/438/EEC (Official Controls Regulation). Official Journal of the European Union 95: 1-142.

European Commission (EC), 2019. Commission Delegated Regulation (EU) 2019/625 of $4^{\text {th }}$ March 2019 supplementing Regulation (EU) 2017/625 of the European Parliament and of the Council with regard to requirements for the entry into the Union of consignments of certain animals and goods intended for human consumption. Official Journal of the European Union 131: 18-30.

Gasco, L., Biasato, I., Dabbou, S., Schiavone, A. and Gai, F., 2019. animals fed insect-based diets: state-of-the-art on digestibility, performance and product quality. Animals 9: 170. https://doi. org/10.3390/ani9040170

Hanboonsong, Y., Jamjanya, T. and Durst, P.B., 2013. Six-legged livestock: edible insect farming, collection and marketing in Thailand. Food and Agriculture Organization of the United Nations RAP Publications 2013/03, Bangkok, Thailand. Available at: http:// www.fao.org/3/i3246e/i3246e.pdf.

Hartmann, C. and Siegrist, M., 2017. Consumer perception and behaviour regarding sustainable protein consumption: a systematic review. Trends in Food Science \& Technology 61: 11-25. https:// doi.org/10.1016/j.tifs.2016.12.006

Henchion, M., Hayes, M., Mullen, A.M., Fenelon, M. and Tiwari, B., 2017. Future protein supply and demand: strategies and factors influencing a sustainable equilibrium. Foods 6: 53. https://doi. org/10.3390/foods6070053

Henry, A.E. and Story, M., 2009. Food and beverage brands that market to children and adolescents on the internet: a content analysis of branded web sites. Journal of Nutrition Education and Behavior 41: 353-359. https://doi.org/10.1016/j.jneb.2008.08.004

House, J., 2016. Consumer acceptance of insect-based foods in the Netherlands: academic and commercial implications. Appetite 107: 47-58. https://doi.org/10.1016/j.appet.2016.07.023 
International Platform of Insect as Food and Feed (IPIFF), 2019a. Regulation EU 2015/2283 on novel food. Briefing paper on the provisions relevant to the commercialization of insect-based products intended for human consumption in the EU. IPIFF, Brussels, Belgium, 44 pp. Available at: https://tinyurl.com/y2jdgs4j. International Platform of Insect as Food and Feed (IPIFF), 2019b. The European insect sector today: challenges, opportunities and regulatory landscape. IPIFF, Brussels, Belgium, 16 pp. Available at: https://tinyurl.com/tr664sq.

International Platform of Insect as Food and Feed (IPIFF), 2019c. Information note: latest regulatory developments regarding the establishment of EU import conditions for insects intended for human consumption. IPIFF, Brussels, Belgium, 7 pp. Available at: https://tinyurl.com/u8jtx53.

Kasemsap, K., 2018. The importance of electronic commerce in modern business. In: Mehdi Khosrow-Pour, D.B.A. (eds.) Encyclopedia of information science and technology (4th ${ }^{\text {th }}$ Ed.). Information Resources Management Association, USA, pp. 2791-2801. https:// doi.org/10.4018/978-1-5225-2255-3.ch243

Kim, S.W., Less, J.F., Wang, L., Yan, T., Kiron, V., Kaushik, S.J. and Lei, X.G., 2019. Meeting global feed protein demand: challenge, opportunity, and strategy. Annual Review of Animal Biosciences 7: 221-243. https://doi.org/10.1146/annurev-animal-030117-014838

Le Féon, S., Thévenot, A., Maillard, F., Macombe, C., Forteau, L. and Aubin, J., 2019. Life Cycle Assessment of fish fed with insect meal: case study of mealworm inclusion in trout feed, in France. Aquaculture 500: 82-91. https://doi.org/10.1016/j. aquaculture.2018.06.051

Lock, E.J., Biancarosa, I. and Gasco, L., 2018. Insects as raw materials in compound feed for aquaculture. In: Halloran, A., Flore, R., Vantomme, P. and Roos, N. (eds.) Edible insects in sustainable food systems. Springer International Publishing AG, Cham, Switzerland, pp. 263-276. https://doi.org/10.1007/978-3-319-74011-9_16

Lombardi, A., Vecchio, R., Borrello, M., Caracciolo, F. and Cembalo, L., 2019. Willingness to pay for insect-based food: the role of information and carrier. Food Quality and Preference 72: 177-187. https://doi.org/10.1016/j.foodqual.2018.10.001

Lotta, F., 2019. Insects as food: the legal framework. In: Sogari, G., Mora, C. and Menozzi, D. (eds.) Edible insects in the food sector. Springer Nature, Cham, Switzerland. https://doi.org/10.1007/9783-030-22522-3_8.

Macombe, C., Le Feon, S., Aubin, J. and Maillard, F., 2019. Marketing and social effects of industrial scale insect value chains in Europe: case of mealworm for feed in France. Journal of Insects as Food and Feed 5: 215-224. https://doi.org/10.3920/JIFF2018.0047

Mancuso, T., Baldi, T. and Gasco, L., 2016. An empirical study on consumer acceptance of farmed fish fed on insect meals: the Italian case. Aquaculture International 24: 1489-1507. https://doi. org/10.1007/s104.99-016-0007-z

Mancuso, T., Pippinato, L. and Gasco, L., 2019. The European insects sector and its role in the provision of green proteins in feed supply. Quality - Access to Success 20: 374-381.

Melgar-Lalanne, G., Hernández-Álvarez, A.J. and Salinas-Castro, A., 2019. Edible insects processing: traditional and innovative technologies. Comprehensive Reviews in Food Science and Food Safety 18: 1166-1191. https://doi.org/10.1111/1541-4337.12463
Meticulous Research, 2019. Edible insects market by product type (whole insect, insect powder, insect meal, insect type (crickets, black soldier fly, mealworms), application (animal feed, protein bar and shakes, bakery, confectionery, beverages) - global forecast to 2030. Meticulous Market Research Pvt. Ltd., Pimpri-Chinchwad, India, 228 pp. Available at: https://www.meticulousresearch.com/ product/edible-insects-market-forecast/.

Orsi, L., Voege, L.L. and Stranieri, S., 2019. Eating edible insects as sustainable food? Exploring the determinants of consumer acceptance in Germany. Food Research International 125: 108573. https://doi.org/10.1016/j.foodres.2019.108573

Payne, C.L.R., Scarborough, P., Rayner, M. and Nonaka, K., 2016. Are edible insects more or less 'healthy' than commonly consumed meats? A comparison using two nutrient profiling models developed to combat over-and undernutrition. European Journal of Clinical Nutrition 70: 285-291. https://doi.org/10.1038/ejcn.2015.149

Piha, S., Pohjanheimo, T., Lähteenmäki-Uutela, A., Křečková, Z. and Otterbring, T., 2018. The effects of consumer knowledge on the willingness to buy insect food: an exploratory cross-regional study in Northern and Central Europe. Food Quality and Preference 70: 1-10. https://doi.org/10.1016/j.foodqual.2016.12.006

Rumpold, B.A. and Schlüter, O.K., 2013. Nutritional composition and safety aspects of edible insects. Molecular Nutrition \& Food Research 57: 802-823. https://doi.org/10.1002/mnfr.201200735

Shelomi, M., 2015. Why we still don't eat insects: assessing entomophagy promotion through a diffusion of innovations framework. Trends in Food Science \& Technology 45: 311-318. https://doi.org/10.1016/j.tifs.2015.06.008

Smetana, S., Schmitt, E. and Mathys, A., 2019. Sustainable use of Hermetia illucens insect biomass for feed and food: attributional and consequential life cycle assessment. Resources, Conservation and Recycling 144: 285-296. https://doi.org/10.1016/j. resconrec.2019.01.042

Sogari, G., Amato, M., Biasato, I., Chiesa, S. and Gasco, L., 2019a. The potential role of insects as feed: a multi-perspective review. Animals 9: 119. https://doi.org/10.3390/ani9040119

Sogari, G., Menozzi, D., Hartmann, C. and Mora, C., 2019b. How to measure consumers acceptance towards edible insects? A scoping review about methodological approaches. In: Sogari, G., Mora, C. and Menozzi, D. (eds.) Edible insects in the food sector. Springer Nature, Cham, Switzerland, pp. 27-44. https://doi.org/10.1007/9783-030-22522-33

Van Huis, A. and Tomberlin, J.K., 2017. Insects as food and feed: from production to consumption. Wageningen Academic Publishers, Wageningen, the Netherlands, 447 pp. https://doi.org/10.3920/97890-8686-849-0

Van Huis, A., 2019. Insects as food and feed, a new emerging agricultural sector: a review. Journal of Insects as Food and Feed 1: 27-44. https://doi.org/10.3920/JIFF2019.0017

Weber, K., Story, M. and Harnack, L., 2006. Internet food marketing strategies aimed at children and adolescents: a content analysis of food and beverage brand web sites. Journal of the American Dietetic Association 106: 1463-1466. 
